\title{
SURVEY OF CERTAIN INSECTS INFESTING MAIZE CROP AND BIOLOGICAL ASPECTS OF THE PARASITOID, BRACON BREVICORNIS WESM. (HYMENOPTERA: BRACONIDAE) REARED ON SESAMIA CRETICA LED. UNDER LABORATORY CONDITIONS. \\ Habashy, Aml Z. N.; A. A. Abd- Elsamed and A. A. A. Saleh \\ Plant Protection Research Institute, Agric. Res. Center, Dokki, Giza, Egypt.
}

\begin{abstract}
The present study was conducted during two successive seasons in the period from 2011 to 2012 to survey some aphids species Rhopalosiphum maidis (Fitch)., Rhopalosiphum padi (Linnaeus)., Aphis gossypii (Glover)., leafhoppers species Empoasca decipiens (Paoli), Empoasca decedens (Paoli) , Cicadulina chinai (Ghaui) , Balclutha hortensis (Lindb) and Cicadulina bipunctella zeae (China), planthoppers species namely Sogatelle vibix (Haupt) and S. furcifera (Horv.) and two stem borers Sesamia cretica Led, Ostrinia nubilalis Hun infesting maize plants and their associated predators. The ecto-larval parasitoid species, Bracon brevicornis Wesm . was reared in the laboratory on full grown larval of the corn borer, S. cretica Led. Some biological aspects of parasitoid were studied. Total developmental period of immature stages (egg - adult) lasted 16.05 days. Average number of deposited eggs / female was 209.08 eggs. Mean number of eggs deposited per host larva was 8.19 eggs. Sex ratio (male: female) was $1: 0.54$ when the parasitoid was reared on $S$. cretica grown larvae. The results indicated that increase of the parasitoid density, increased the number of host larva parasitized, fecundity and total progeny, while the sex ratio (female \%) was decreased. Adult longevity was affected by temperature and food supplied. Four predators were associated with these insects on maize. These predators were Coccinella undecimpunctata, Metasyrphus Corollae , Chrysoperala carnea and true spiders

Keywords: Aphids, leafhoppers, planthoppers, predators, maize , Bracon brevicornis, biology, Sesamia certica, .
\end{abstract}

\section{INTRODUCTION}

Maize (Zea mays L.) is one of the most important cereal crops in Egypt. It is subjected to infestation with a variety of insect pests (Tawfik et al., 1974). The homopterous insects (aphids, leafhoppers and planthoppers ) and two stem borers are economic pests of many agricultural crops in Egypt. Maize plants are infested by these insect pests which affect the quantity of yield as results of their direct feeding on plant, in addition, The homopterous insects are responsible for natural spread of several virus diseases to maize plants (Nielson, 1968 and Hegab,Ola 2001 ). Among these pests, Sesamia cretica Led. is considered one of the most destructive agricultural pests which causes serious economic damage and reduces the crop yield. This pest species is difficult to be controlled by contact insecticides because the larvae bore into plant tissues shortly after hatching. In addition, pesticides residues in food are becoming increasingly unacceptable to consumers. 
Habashy, AmI Z. N. et al.

The parasitoid, Bracon brevicornis Wesm. is an indigenous, primary gregarious ectoparasitoid on S. cretica, O. nubilalis $\mathrm{Hb}$.; Chilo Agamemnon Bles.; Helicoerpa armigera (Hubner) and Pectinophora gossypiella (Saunders.). The parasitoid is widely distributed over lower and upper Egypt and has 24 generations in the laboratory per year (Megahed et al.,1981 and Kares et al., 2009). Several authors over the world have recorded the parasitoid on different hosts; In India and Srylanka the parasitoid was recorded parasitized Opisina arenosella Walker (Pillai and Nair 1995) and cashew leaf and blossom Webber Lamida moncusalis Walker (Mohapatra and Mohapatra 2003). In Iran (Habibpour et al., 2002) surveyed insects and a mites associated with stored products and their parasitoids, B. brevicornis was among the natural enemies of these pests. In Germany (Politz et al., 2007 ) detected parasitism of $O$. nubilalis by $B$. brevicornis. Several authors studied the biology of this parasitoid (Lutfallah and Kares 1989; El- Mandrawy 1997 and Kares et al., 2009).

Aim of this investigation is to survey certain insects on maize and study some biological parameters of the parasitoid, B. brevicornis on full grown larvae of $S$. cretica

\section{MATERIALS and METHODS}

Sampling started when the age of maize plants reached about 21-28 days after sowing and continued at weekly intervals throughout the two growing seasons. The following procedures of sampling were adopted:

2. 1- a) Plant samples, six leaves representing different strata, viz. terminal, middle and bottom parts and tassel were taken from randomly chosen five plants. These leaves and tassels were examined in the laboratory using a binocular microscope and the total number of existing nymphs, aptera, and alate forms of aphids and their associated predators on both surfaces of the leaves and tassels were recorded.

b) Sweeping net, $30 \mathrm{~cm}$ diameter and $60 \mathrm{~cm}$ deep. Each sample consisted of 100 double strokes were taken from both diagonal directions of the experimental area. Each sample was kept in a tight closed paper bag and transferred to the laboratory for inspection by binocular microscope and the collected leafhoppers and planthoppers were killed by cyanide, sorted into species and identified according to the work of Ribaut (1952), Nielson (1968) and Hegab et .al. (1989). Counts of captured leafhoppers were recorded for each sample.

c) Plant sample survey of corn stem borers, this investigation was conducted to survey of stem borers, S. cretica and $O$. nubilalis on maize plants. Soon after 15 days from germination of plants, 5 plants were randomly chosen and dissected weekly to estimate the infested plants and calculate numbers, number of larvae and number of pupae on maize plants during the growing season.

The experimental of biology were carried out at Plant Protection Research Institute, Sharkia Branch, Agricultural Research Center. 


\section{Rearing of S. cretica}

Full grown hibernated larvae of $S$. cretica was collected from stored corn stalks. Groups of 10 larvae, each were confined in glass jar $(20 \times 25 \mathrm{~cm})$ and provided with pieces of soft tissue papers to serve as pupation sites. Jars were covered on the top by muslin cloth and were kept until pupation. Pupae were separated and each group was kept in glass jar and provided at the bottom by moistened soft tissue papers and kept in position by rubber bands for moths emergence.

Ovipositional cage consisted a maize seedling in in a plastic pot $S$. cretica moths were placed in the ovipositional cage and covered with muslin. Within each cage, the moths were provided with a piece of cotton moistened with $10 \%$ honey solution for feeding. Deposited eggs were collected and placed into envelopes of fresh green maize ears, as suitable food supply for hatching larvae. The infested ears were placed into glass jar, cored with muslin cloths. Fresh green maize ears were renewed as the larvae grew older and so on until full grown larvae were obtained.

\section{Rearing of the parasitoid, $B$. brevicornis :}

Laboratory culture of $B$. brevicornis began with parasitized hibernated larvae of $S$. certica, collected from maize stalks. The parasitized larvae was separated individually in glass tubes $(9 \times 2 \mathrm{~cm})$. Cocoons were confined in glass jar $(1 / 2 \mathrm{~kg})$, covered with muslin. After emergence, adults were paired and provided by small droplets of bee honey scattered on the inner wall of each jar for feeding. Emerged parasitoid was mounted and identified at the Department of Biological Control, Agriculture Research Center, Egypt.

\section{Biological aspects of the parasitoid, B. brevicornis}

The experiments were carried out under the laboratory conditions of $25^{\circ} \mathrm{C} \pm 2$ and $64 \pm 4 \% \mathrm{RH}$. to study the biology of $B$. brevicornis on the full grown larvae of $S$. cretica. One pair of fresh parasitoid adults emerged was confined in a glass jar and replicated ten times. After the full grown larvae of $S$. cretica were introduced for one day to the jar, the larvae were examined and those carried parasitoid eggs were removed individually and kept in Petri-dish $(10 \mathrm{~cm})$ under the same controlled conditions. Fresh larvae were introduced again into the jars and this method was continued until death of the parasitoid adults. The numbers of deposited eggs were counted daily. The parasitized larvae of $S$. cretica, which were separated individually inside Petri - dishes, were daily examined till the emergence of the parasitoid adults. The parasitized larvae were observed under a dissecting stereomicroscope to estimate incubation period of eggs and duration periods of larvae and pupae. Sex ratio and male and female longevity were also estimated.

Effect of temperature and food supply on the adult longevity of $B$. brevicornis.

Forty pairs of mated females and males of the parasitoid $B$. brevicornis were obtained from the laboratory culture, (24 hours) after adults emergence. They were divided into four groups, each of ten individuals, group (A) starved females and males, group (B) both sexes were supplied daily with droplets of honey, gropes $A$ and $B$ were kept at room temperature 
(average $23^{\circ} \mathrm{C}$ ). Group $(\mathrm{C})$ adult females and males were also starved and group (D) was supplied daily with droplets of honey. The two groups C and D were kept in a refrigerator at $10^{\circ} \mathrm{C}$ however Stary (1970).

Effect of parasitoid densities on parasitization rate:

The experiments were carried out in glass jars, $(20 \times 10 \mathrm{~cm})$ twenty larvae of $S$. cretica were placed in each jar, provided with moistened soft tissue paper. Using different densities of the parasitoid, (female and male ) $1 \hat{\jmath}+1 q, 2 \hat{\jmath}+2 q, 4 \hat{\jmath}+4 q$ and $8 \hat{\jmath}+8 q$. The last parasitoid densities were gently introduced into each jar contained 20 full grown larvae of $S$. cretica . After one day, the parasitoids were removed, the host larvae (S. cretica) were left and the parasitized larvae were counted, calculated the number of parasitoid eggs, Adult emergence rate and sex ratio were estimated. Five replicates were performed for each parasitoid density. Costat software program (1990) was used for statistical analysis of the data.

\section{RESULTS AND DISSCUSION}

\section{Survey of some homopterous insects on maize plants}

a) Aphid species:

Survey studies on maize plants in Diarb-Nigm, district, Sharkia Governorate revealed the presence of the following aphid species Rhopalosiphum maidis (Fitch)., Rhopalosiphum padi (Linnaeus)., Aphis gossypii (Glover).

b)Leafhopper insects:

The data presented in Table (1) showed the incidence of five leafhopper species belonging to family Cicadellidae on maize crop. The collected leafhopper species were arranged descendingly according to their abundance as follows: Empoasca decipiens (Paoli), Empoasca decedens (Paoli) , Cicadulina chinai (Ghaui) , Balclutha hortensis (Lindb) and Cicadulina bipunctella zeae (China)

Table (1): Total number of aphids, leafhoppers, planthoppers, stem borers and predator insect species collected from maize plants by using plant samples and sweeping net traps in Diarb- Nigm district, Sharkia Governorate during 2011 and 2012 seasons

\begin{tabular}{|c|c|c|c|c|c|}
\hline \multirow{2}{*}{\multicolumn{2}{|c|}{ Insects }} & \multicolumn{2}{|c|}{2011} & \multicolumn{2}{|c|}{2012} \\
\hline & & Plant S. & S.N.T. & Plant S. & S.N.T. \\
\hline \multirow{3}{*}{$\begin{array}{l}\frac{0}{0} \\
\frac{1}{2} \\
\frac{0}{4}\end{array}$} & R. maidis & 39861 & 17 & 49752 & 10 \\
\hline & R. padi & 20651 & 33 & 41852 & 17 \\
\hline & A. gossypii & 4552 & 12 & 8721 & 5 \\
\hline \multirow{7}{*}{ 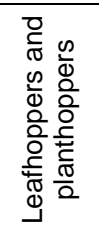 } & E. decipiens & 3 & 1550 & 7 & 2870 \\
\hline & E. decedens & 6 & 1340 & 10 & 2041 \\
\hline & C. chinai & 3 & 842 & 2 & 1055 \\
\hline & C. bipunctalla zeae & - & 270 & - & 420 \\
\hline & B. hortensis (Lindb) & - & 412 & 1 & 1174 \\
\hline & S. vibix (Haupt) & 3 & 1052 & 4 & 2410 \\
\hline & S. furcifera (Horv) & 2 & 971 & 5 & 2652 \\
\hline \multirow{2}{*}{$\begin{array}{c}\text { Stem } \\
\text { Borers }\end{array}$} & Sesamia cretica Led. & 510 & - & 460 & - \\
\hline & Ostrinia nubilalis Hun. & 295 & - & 342 & - \\
\hline \multirow{4}{*}{$\begin{array}{l}\frac{N}{0} \\
\frac{0}{0} \\
\frac{\pi}{0} \\
\Phi \\
\frac{\Phi}{2}\end{array}$} & C. undecmpunctata & 81 & 6 & 103 & 3 \\
\hline & M. corollae F. & 76 & 3 & 93 & 4 \\
\hline & Ch. carnea & 119 & 2 & 107 & 5 \\
\hline & True spiders & 71 & 10 & 87 & 8 \\
\hline
\end{tabular}


c) Planthopper insects:

The following planthopper species namely Sogatelle vibix (Haupt) and S. furcifera (Horv.) were collected from maize plants during 2011 and 2012 seasons.

\section{d) Two stem borers insects:}

The following two stem borers insects $S$. cretica, $O$. nubilalis were collected from maize plants during 2011 and 2012 seasons. The total numbers of these species were $S$. cretica (510 and 460 individuals), $O$. nubilalis (295 and 342 individuals) in the two seasons respectively. Guofa et al., (2002) ; Velasco (2004); Saeed et al., (2009) and Alireza et al., (2010). e) Predators:

Data in Table (1) showed the predator species on maize plants during 2011 - 2012 seasons. These species were belonging order coleoptera, Diptera and Neuroptera. The total numbers of these species were C. undecmpunctata(81 and 103 individuals), M. corollae (76 and 93 individuals) and Ch. carnea (119 and 107 individuals). Mean while true spiders (71 and 87individuals) during the two seasons of study. However, Darwish and ali (1991) reported that predators comprised about $88 \%$ of the total natural enemies recorded in maize fields in upper Egypt.

The experiment of biological

Data in Table (2) showed some of the biological aspects of the parasitoid $B$. brevicornis under the laboratory conditions of $25 \pm 2 \stackrel{\circ}{ } \mathrm{C}$ and 60 $\pm 4 \mathrm{RH}$. Incubation period of eggs lasted for $2-3$ days, with an average of $2.72 \pm 0.11$ days. Percentage of hatchability was $95.97 \%$.

Larval stage lasted an average of $5.35 \pm 0.47$ days with a range of 4 - 7 days. Mortality percentage was $3.17 \%$. The pupal period ranged from $7-9$ days, with an average $7.98 \pm 0.73$ days. The total developmental period (egg - adult) lasted of $14-18$ days, with an average of $16.05 \pm 1.44$ days.

Mean percentage of adult emergence was $95.74 \%$. Sex ratio was 1 male: 0.54 female. The pre -ovipositoinal period of adult females, supplied with $S$. cretica full grown larvae was $1.67 \pm 0.33$ days, with a range of $1-2$ days. Ovipositoinal period was $21.17 \pm 1.78$ days, with a range of $13-25$ days. Postovipositional period was $2.67 \pm 0.74$, days with a range of $2-4$ days. The mean female longevity was $25.51 \pm 2.20$ with a range of $16-29$ days. The mean male longevity was $12.67 \pm 0.84$ with a range of $9-15$ days. Mean number of deposited eggs $B$. brevicornis was 209.08 eggs/ femal, with a range of $121-339$ eggs, Mean number of eggs/ host larva was 8.19 egg when the parasitoid reared on $S$. cretica full grown larvae. Temerak (1984b) stated that the female of $B$. brevicornis, supplied daily with afresh $S$. cretica larva lived significantly longer than those kept with unchanged larvae. Obtained results are in agreement with the findings of Megahed et al.,(1981) who studied the effect of six different host species, including $S$. cretica and A. ipsilon, on sex ratio of $B$. brevicornis reared at $27^{\circ} \mathrm{C} \& 65 \mathrm{R} . \mathrm{H}$. The sex ratio differed according to the species of host larva. Highest sex ratio (females : males) 2.06:1 was obtained in case of $A$. ipsilon. Lutfallah and Kares (1989) reported that laboratory rearing of $B$. brevicornis, at $27^{\circ} \mathrm{C}$ \& $65 \%$ R.H. on S. cretica. showed a sex ratio of 1 female : 1.37 male, at which a slight increase in the ratio of males was found comparing to that (1 
female: 1.19 male) on O. nubilalis. On the other hand, Kares et al., (2009) showed that mean number of parasitoid progeny / host larvae was 9.3 (on $S$. cretica ) when the host larvae were exposed daily to the parasitoid female and 11.4 when the host larvae were exposed every two days. Sex ratio (male : female) was found to be $1: 0.3$ when the parasitoid was reared on $S$. cetica, also found that an ovipositional period of adult females of $B$. brevicornis, which were supplied daily and every two days with $S$. cretica larvae were 30.6 and 20.0 days, respectively.

Table (2): Biological aspects of the parasitoid Bracon brevicornis when reared on $S$. cretica under laboratory condition $25 \pm 2^{\circ} \mathrm{C}$ and $60 \pm 4 \%$ RH.

\begin{tabular}{|c|c|c|c|}
\hline \multirow{2}{*}{\multicolumn{2}{|c|}{ Stage }} & \multicolumn{2}{|c|}{ Duration in days } \\
\hline & & Range & Mean \pm SE \\
\hline \multirow{2}{*}{ Egg } & Incubation period & $2-3$ & $2.72 \pm 0.11$ \\
\hline & Hatchability \% & $90-100 \%$ & $95.97 \%$ \\
\hline \multirow{2}{*}{ Larva } & Duration & $4-7$ & $5.035 \pm 0.47$ \\
\hline & Mortality & - & $3.17 \%$ \\
\hline \multicolumn{2}{|r|}{ Pupal period } & $7-9$ & $7.98 \pm 0.73$ \\
\hline \multicolumn{2}{|c|}{ Total developmental period (egg- adult) } & $14-18$ & $16.05 \pm 1.44$ \\
\hline \multicolumn{2}{|c|}{ Adult emergence \% } & - & $95.74 \%$ \\
\hline \multicolumn{2}{|c|}{ Sex ratio ( Male: Female) } & - & $1: 0.54$ \\
\hline \multirow{4}{*}{ 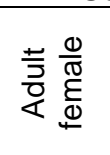 } & Pre-ovipositional period & $1-2$ & $1.67 \pm 0.33$ \\
\hline & Ovipositional period & $13-25$ & $21.17 \pm 1.78$ \\
\hline & Post-ovipositional period & $2-4$ & $2.67 \pm 0.74$ \\
\hline & Female longevity & $16-29$ & $25.51 \pm 2.20$ \\
\hline \multicolumn{2}{|r|}{ Male longevity } & $9-15$ & $12.67 \pm 0.84$ \\
\hline \multicolumn{2}{|c|}{ No. of eggs / female } & $121-339$ & $209.08 \pm 4.1$ \\
\hline \multicolumn{2}{|c|}{ No. of eggs / larva } & $2-21$ & $8.19 \pm 0.901$ \\
\hline
\end{tabular}

Gunduz and Gulel (2005) indicated that the developmental period of parasitoid $B$. brevicornis from egg to adult was $11-13$ days when the parasitoid was reared on Galleria mellonella L. and $12-14$ days on $E$. kuehnielle.

Table (3) shows effect of parasitoid densities on the number of host larvae parasitized, fecundity and sex ratio, reared on $S$. cretica under laboratory conditions. With increase of the parasitoid density parasitoids / jar $8 \hat{0}+8$, number of parasitized host larvae increased to $15.5 \pm 0.51$ at and the minimum $(5.4 \pm 0.49)$ was recorded at $(1 \hat{\delta}+1$ 우 $)$ parasitoid per jar. Significant differences were found among the larvae of $S$. certica parasitized with $B$. brevicornis at varying densities. Also, parasitized larva was increased of the parastoid density the total number eggs laid/ parasitized larvae were increased with amaximum of $202.2 \pm 1.59$ eggs at $8 \hat{0}+8+$ and a minimum (86.4 \pm 0.75 eggs at $1++1$ ) . Total progeny of parasitoids female increased as the parasitoid density increased. The mean sex ratio (female \%) was decrease by the increase of the parasitoid density. The mean sex ratio (female \%) were 44.78, 40.08, 29.94 and 25.0 at $1 \hat{\sigma}+1 \%, 2 \hat{\circ}+2$, $4 \hat{\circ}+4 \%$ and $8 \hat{O}+8$ r respectively. 
Obtained results are in agreement with the findings of Holling (1959) indicted that the number of hosts attacked (paralyzed and oviposited hosts) increased with host density increased. The parasitoid would spend more time traveling among hosts as the density increased. Consequently, the total time for ovipositoin could be decreased.

Fuester et al.,(2003) reported similar results for the braconid Glypantales flavicoxis. The male biased sex ratio may be the result of a varity of factors, including sperm depletion, sperm death, physiological aging, active sperm digestion by the female, sperm disintegration while stored in the sperm thecae, the number of copulations and the differential mortality of the sexes during larval development (Uckan and Gulel, 2002; Damiens el al., 2003; Fuester et al.,2003). Differential mortality has been implicated in several studies of competition in gregarious parasitoids but typically female larvae suffer more than males. Taking into consideration that $B$. hebetor not only lays an average of 12.6 eggs when it is supplied with only one host per day (Yu et al., 2003), but also records increased mortality of immature when the number of eggs laid on a single host is more than eight (Yu 1999), it may be assumed that extreme immature mortality caused this significant decrease.

Table (3): Effect of parasitoid densities on the number of hosts larvae parasitized, number eggs laid/host larvae and sex ration of Bracon brevicornis, reared on Sesmia cretica under the laboratory condition ( $25 \pm 2^{\circ} \mathrm{C}$ and $64 \pm 4 \% \mathrm{RH}$.)

\begin{tabular}{|c|c|c|c|c|c|c|}
\hline \multicolumn{7}{|c|}{ Mean \pm SE } \\
\hline \multirow[b]{2}{*}{$\begin{array}{c}\text { Parasitoid } \\
\text { density }\end{array}$} & \multirow[b]{2}{*}{$\begin{array}{c}\text { No. of hosts } \\
\text { larva } \\
\text { parasitized }\end{array}$} & \multirow{2}{*}{\begin{tabular}{|c|} 
Total \\
number of \\
eggs \\
laid/ \\
hosts larva
\end{tabular}} & \multicolumn{3}{|c|}{ Adult emergence } & \multirow[b]{2}{*}{ Females $\%$} \\
\hline & & & Male & Female & $\begin{array}{c}\text { Total } \\
\text { progeny }\end{array}$ & \\
\hline $1 \hat{\delta}+1 q$ & $5.4 \pm 0.49^{d}$ & $\begin{array}{l}86.4+\frac{+}{d} \\
0.75^{\text {d }}\end{array}$ & $43.4 \pm 1.08^{d}$ & $35.2 \pm 1.28^{c}$ & $78.6 \pm 1.5^{d}$ & $44.78 \pm 0.58^{d}$ \\
\hline $2 \lambda+2 q$ & $8.6 \pm 0.50^{c}$ & $\begin{array}{c}110.8 \pm \\
2.74^{c}\end{array}$ & $62.2 \pm 0.97^{c}$ & $41.6 \pm 1.08^{b}$ & $103.8 \pm 1.59^{c}$ & $40.08 \pm 1.16^{c}$ \\
\hline $4 \hat{\jmath}+4 \bigcirc$ & $\begin{array}{l}11.2 \pm \\
0.58^{\mathrm{b}}\end{array}$ & $\begin{array}{c}145.8 \pm \\
2.19^{b}\end{array}$ & $90.8 \pm 1.07^{b}$ & $38.8 \pm 1.16^{b c}$ & $129.6 \pm 2.18^{b}$ & $29.94 \pm 1.73^{b}$ \\
\hline $8 \hat{\sigma}+8+$ & $0.51^{\mathrm{a}}$ & $\begin{array}{c}202.2 \pm \\
1.59^{a}\end{array}$ & $137.4 \pm 1.15^{a}$ & $45.8 \pm 1.43^{a}$ & $183.2 \pm 2.37^{a}$ & $25.0 \pm 0.79^{a}$ \\
\hline $\mathrm{F}$ & $\begin{array}{c}\star \star \star \\
66.933\end{array}$ & $\begin{array}{c}\star \star \\
652.31\end{array}$ & $\begin{array}{c}\star \star \star \\
1455.127\end{array}$ & $\begin{array}{c}* \star \\
12.989\end{array}$ & $\begin{array}{c}\star \star \star \star \\
526.757\end{array}$ & $\begin{array}{c}* \star \\
166.198\end{array}$ \\
\hline
\end{tabular}

Effect of temperature and food supply on longevity of Bracon brevicornis

Data in Table (4) showed that adult longevity of starved female was longer than that of starved males, when both were kept, at room temperature of $23 \stackrel{\circ}{\circ} \pm$ (Group A). Also, the female lived longer than male when fed at the room temperature (Group B) Starved or fed females lived longer than males when kept in the refrigerator at $10{ }^{\circ} \mathrm{C} \pm$ (Groups $\mathrm{C}$ and $\mathrm{D}$ ) however Stary 1970 showed that the adult life span of parasitoid was affected by many factors such as temperature, humidity, food and presence or absence of hosts. 
Habashy, AmI Z. N. et al.

Table (4): Effect of temperature and food supply on the longevity of Bracon brevicornis, emerged from Sesmia cretica.

\begin{tabular}{|c|c|c|c|c|c|c|}
\hline \multirow{3}{*}{ Groups } & \multirow{3}{*}{ Treatment } & \multirow{3}{*}{ Temp ${ }^{\circ} \mathrm{C}$} & \multicolumn{4}{|c|}{ Adult longevity in days } \\
\hline & & & \multicolumn{2}{|c|}{ Female } & \multicolumn{2}{|c|}{ Male } \\
\hline & & & Range & Mean \pm S.E. & Range & Mean $\pm S . E$. \\
\hline A & - & 23 & $17-22$ & $19.3 \pm 0.47^{\mathrm{d}}$ & $10-17$ & $13.6 \pm 0.40^{\circ}$ \\
\hline$B$ & + & 23 & $25-28$ & $26.1 \pm 0.31^{c}$ & $18-22$ & $19.5 \pm 0.40^{\circ}$ \\
\hline C & - & 10 & $28-32$ & $30.1 \pm 0.48^{b}$ & $21-31$ & $24.5 \pm 1.08^{\mathrm{b}}$ \\
\hline $\mathrm{D}$ & + & 10 & $32-44$ & $39.1 \pm 1.36^{a}$ & $29-34$ & $31.5 \pm 0.45^{\mathrm{a}}$ \\
\hline & $F$ & & & ** 119.0122 & & ** 116.047 \\
\hline
\end{tabular}

- Unfed + supplied with droplets of honey $\quad{ }^{*}$ Means of the same letter

\section{ACKNOWLEDGMENTS}

Deep Thanks to Prof. Dr. E. A. Kares and Prof. Dr. H. A. A. Abulfadl, Biological Control Department, Plant Protection, Research Institute, Agriculture Research Center, Giza, Egypt, for identification of the parasitoid species

\section{REFERENCES}

Alireza, A.; M. Saeed; K. Karim and F. Yaghub (2010). Evaluation of damage caused by stalk borers, Sesamia spp. (Lepidoptera: Noctuidae), on sugar cane quality in Iran .Zeitschrift für Angewandte Entomologie, 62(2):110-117.

Costat, S. (1990): Microcomputer program analysis; version $4-20$ Cohort Software, Berkley CA, USA.

Damiens, D.; C. Bressac and C.Chevrier(2003):The effect of age on sperm stock and egg laying in the parasitoid was P. Dinarmus basalis. J.Insect. Sci. 3: 22.

Darwish, Y.A. and A.M. Ali (1991): Field population trends of cereal aphid and their natural enemies on corn plants in upper Egypt. Assiut. J. Agric. Sci., 22(2):33- 42.

El-Mandarawy, M.I.B.R. (1997): Effects of insect diapause and parasitiztion of a bracond Bracon brevicornis Wesm. On the haemolymph of its host Sesamia certica Led. Journal of the Egyptian Society of parasitology. 27(3): $805-815$.

Fuester, R.W., K.S. Dunning, P.B. Taylor and G. Ramaseshiah (2003): Male - biased sex ratio in Glyptapantales flavicoxis (Hymenoptera : Braconidae), a parasitoid of the Gypsy moth Braconidae). Ann. Entomol. Soc. Am. 96: 553 - 559.

Gunduz, N.E.A. and A. Gulel (2005): Effects of adult age and host species on development period of parasitoid Bracon hebetor (Say)( Hymenoptera :Braconidae). J. of Fac. of Agric., OMU, 20(2) : 31 - 36.

Guofa, Z.; W. A. Overholt and M. B. Mochiah (2002). Changes in the distributions of lepidopteran maize stem borers in Kenya s. Insect $\square$ $1990 \square$ from 1950 science and its application 21:395-402.

Habibpour, B.; K. Kamali and J. Meidani (2002): Insects and mites associated with stored products and their arthropod parasites and predator in Khuzestan province (Iran). Bulletin - OILB / SROP, 
Hegab, A. M.; M. M. El Zohairy and M. M. Helaly (1989):Survey and seasonal abundance of leafhoppers infesting certain Solanacous vegetable plants in newly reclaimed sandy areas at Salhia district ,Egypt. Zagazig J.Agric.Res. 6(2): 175-187.

Hegab,Ola I. M. (2001): Studies on certain insect vectors of plant pathogenic agents.Ph. D. Thesis, Fac Agric. Zagazig Univ.

Holling, C.S. (1959): Some characteristics of simple types of predation and parasitism. The Canadian Entomologist, 91: 385 - 398.

Kares, E.A.; G.H. Ebaid and I.A. EL-Sappagh (2009): Biological studies on the larval parasitoid species, Bracon brevicornis Wesm. (Hymenoptera: Braconidae), Reared on different insect hosts. Egyptian Journal of Biological Pest Control, 19(2): 165 - 168.

Lutfallah, A.F. and E.A. Kares (1989): Ecological and biological observation on Bracon brevicornis Wesm. (Hymenoptera : Bracnidae), a parasitoid on corn borers in Egypt. Bull. Soc. Ent Egypt, 68: 187 - 193.

Megahed,M.M.; N.A. Abou- Zeid; M.S.I. EL- Dakroury and M.S.T. Abbas (1981): On the biology of adult Bracon brevicornis Wesm. in the laboratory (Hymenoptera: Braconidae). Res. Bull. No 435. Fac. Of Agric. Zagazig Univ.,11 - 20.

Mohapatra, L.N. and R. Mohapatra (2003): Incidence of cashew leaf and blossom Webber, Lamida moncusalis Walker ( Lepidoptera : Pyralidae) in relation to its natural enemis and weather factors. Indian J. of Plant Protection, 31(1): $119-121$.

Neilson, M. W. (1968): The leafhopper vectors of phytopathogenic viruses (Homoptera:Cicadellidae) taxonomy, biology and virus transmission. Agric .Ser .M.S.Dept.Agr.89.386.

Ribaut,H.(1952): Homopterea Auchenorhyneques II Jassidae faunde France, $57: 1-474$

Pillai, G.B. and K.R. Nair (1995): Superiority of the solitary parasitoids over gregarious species in the biological suppression of the coconut caterpillar Opisina arenosella Walker. J. of Plantation Crop, 23(1): 19 27.

Politz, B.; H. Schnee and A. Kuhne (2007): The infestation status of European corn borer in Saxony occurrence of a second generation for the first time and some natural enemies of the pest. Nachrichtenb latt des Deutschen Pflanzen Schutz Dienstes, 59(11): 264 - 266.

Saeed, A. M.; M. I. Vezic and S. Pancic (2009). Population dynamics of aphid species and evaluation of symptoms of the complex corn stunt in corn hybrids. Ciencia. Agrotecnologia, 26(2):293-300.

Stary,P. (1970): Biology of aphid parasites (Hymenoptera : Aphididae) with respect to integrated control. Series Entomol. Vol. 6Dr. W. Junk The Hague, $643 \mathrm{pp}$.

Tawfik, M.F.S.; M.T. Kira and S.M.T. Metwally (1974): Study of the insect founa of corn fields in Egypt. Bull. Ent. Sco. Egypt. 18: 145 - 152.

Temerak, S.A.(1984b): Studies on certain factors affecting the egg deposition of the parasitoid Bracon brevicornis Wesm. Z. Ang Ent., 97(2): 523 527. 
Habashy, AmI Z. N. et al.

Velasco, P.; P. Soengas ; P. Revilla; A . Ordas and R. A. Malvar (2004). Mean generation analysis of the damage caused by Sesamia nonagrioides (Lepidoptera : Noctuidae) and Ostrinia nubilalis (Lepidoptera : Crambidae) in sweet corn ears. Journal-of- Economic Entomology, 97(1): 120-126.

Uckan, F. and A. Gulel (2002): Age-related fecundity and sex ratio variation in Apantales galleriae (Hymenoptera: Braconidae) and host effect on fecundity and sex ratio of its hyperparasitoid Dibrachys boarmiae (Hymenoptera : Pteromalidae). J. App. Ent. 126: 534 - 537.

Yu, S.H. (1999): Biology of Bracon hebetor. (Hymenoptera: Braconidae) life table and functional numerical and aggregation responses to the host density.M.S. Thesis, Korea University, Seoul, Korea.

Yu, S.H.; M.J. Ryoo; J.H. Na and W.I. Choi.(2003): effect of host density and sex ratio of progeny of Bracon hebetor (Hymenoptera ; Braconidae). J. Stored Prod. Res. 39: $385-393$.

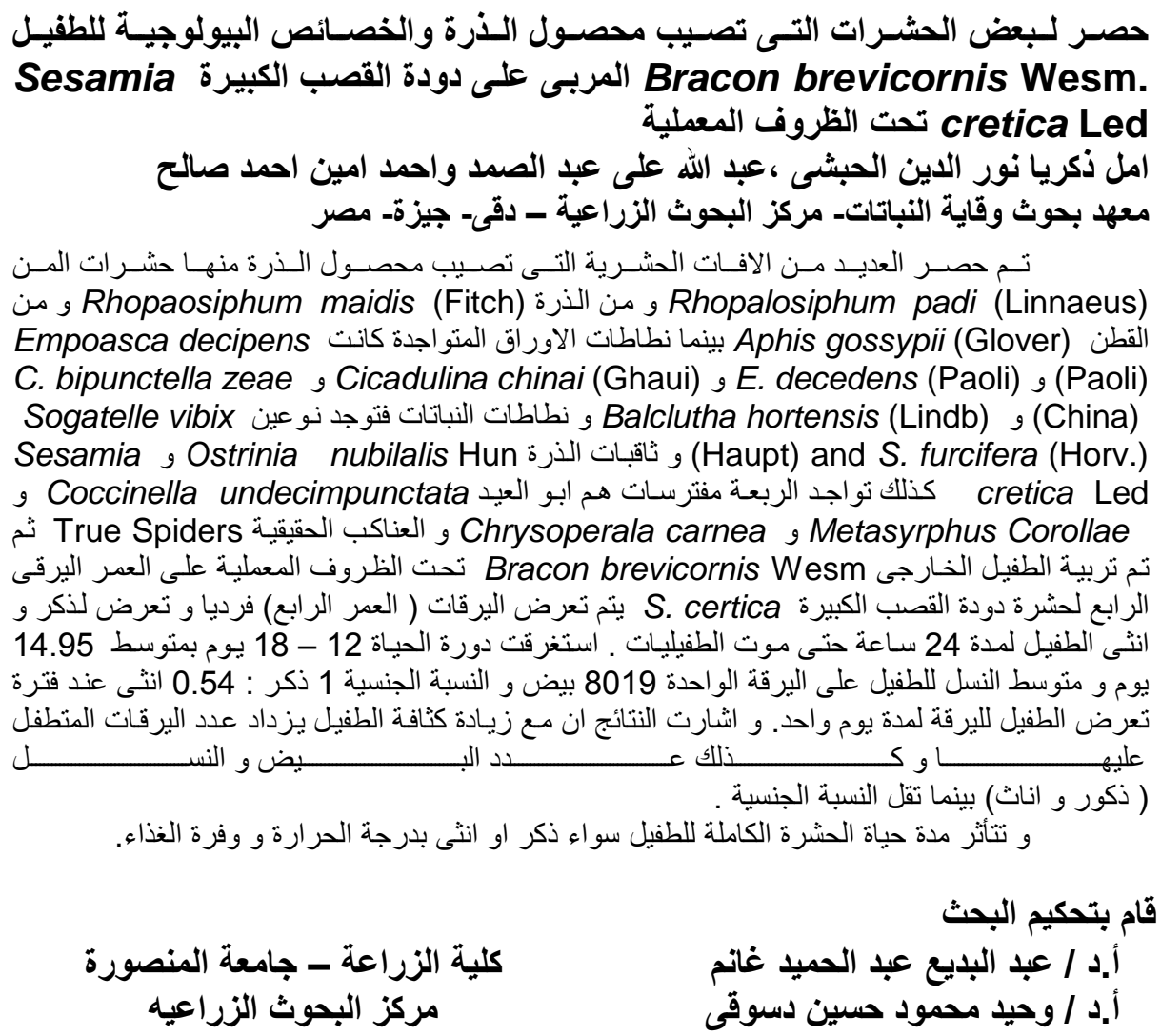

